\author{
MONIKA CHRISTOPH \\ ORCID 0000-0003-4176-6099 \\ Uniwersytet im. Adama Mickiewicza \\ $w$ Poznaniu \\ Ewa KRAUSE \\ ORCID 0000-0002-6639-2639 \\ Uniwersytet Kazimierza Wielkiego \\ w Bydgoszczy
}

\title{
KARIERA ZAWODOWA KOBIET WE WSPÓŁCZESNYCH ORGANIZACJACH
}

\begin{abstract}
Christoph Monika, Krause Ewa, Kariera zawodowa kobiet we wspótczesnych organizacjach [Women's Professional Career in Contemporary Organizations]. Studia Edukacyjne nr 53, 2019, Poznań 2019, pp. 187-208. Adam Mickiewicz University Press. ISSN 1233-6688. DOI: 10.14746/se.2019.53.11

The article presents the specificity of women's professional careers and their situation and social roles in the context of dynamic changes in the labor market: evident intellectualization and digitization of working environments, significantly changing career concepts as well as ways to achieve it. This is particularly important in relation to the career paths of women, mainly due to the need to reconcile work with family responsibilities. Therefore, it becomes important to highlight practical solutions for organizations that aim to create programs to support women in their aspirations and career ambitions, to make work time more flexible and to promote gender diversity in the field of organizational culture.
\end{abstract}

Key words: professional career, women, contemporary organization, social roles, professional roles

\section{Wprowadzenie}

Wzrost znaczenia pracy i kariery zawodowej w życiu kobiet zauważalny jest w końcu XIX wieku. Wówczas w wyniku rewolucji przemysłowej i urbanizacji masowo pojawiły się na rynku pracy. Ich pozycję zawodową wzmocniły pierwsza i druga wojna światowa - zmuszone bowiem były zastąpić mężczyzn przebywających na wojnie $\mathrm{w}$ fabrykach. Istotną rolę $\mathrm{w}$ umocnieniu 
kobiet na rynku pracy odegrała także fala feminizmu występująca w latach 60. i 70. XX wieku, propagująca wśród nich pracę zawodową oraz motywująca je do zajmowania stanowisk równorzędnych mężczyznom. Dopiero od tego momentu można mówić o tak zwanej pozytywnej motywacji kobiet ${ }^{1}$, o szukaniu w pracy zawodowej satysfakcji, możliwości sprawdzenia się czy awansowania ${ }^{2}$.

Współcześnie rozwój kariery zawodowej nabiera dużego tempa i dynamiki. Składa się na to wiele zjawisk $\mathrm{w}$ otoczeniu społeczno-gospodarczym, takich jak: zmiany w sposobach funkcjonowania organizacji i instytucji publicznych, rosnące potrzeby szybkiej adaptacji do oczekiwań współczesnych klientów (które zmieniają się w kontekście usieciowienia życia jednostek), wysoka indywidualizacja życia społecznego i zawodowego, ciągłe redefiniowanie tożsamości społecznej i zawodowej, inwazyjne wkraczanie nowoczesnych technologii w środowiska edukacyjno-zawodowe, wzrastająca mobilność zawodowa, zmniejszona lojalność pracownicza i niska pewność zatrudnienia. W tych kontekstach pracownicy, zarówno kobiety jak i mężczyźni, zaczynają budować proteuszową karierę i/lub karierę bez granic ${ }^{3}$, polegające na zwiększaniu poziomu mobilności, samodzielności i odpowiedzialności za kształt i kierunki rozwoju zawodowego, który znacznie przekracza organizacyjne granice. Współcześnie kluczowym czynnikiem sukcesu w procesie realizacji kariery jest tak zwana zatrudnialność jednostki (employaability), czyli zdolność do zdobywania i utrzymywania przez nią zatrudnienia ${ }^{4}$. Pracownicy chcą zyskiwać zatrudnienie $\mathrm{w}$ takich środowiskach pracy, które dadzą im najlepsze warunki do rozwoju ich „zdolności do bycia zatrudnianym" Taką postawę pracowniczą można określić jako całożyciowe budowanie unikatowego, indywidualnego profilu kompetencyjnego, który oferowany jest poszczególnym pracodawcom, głównie $\mathrm{w}$ ramach tak zwanego zatrudniania projektowego ${ }^{6}$. Obserwujemy więc bardzo dynamiczną zmianę akcentu $\mathrm{z}$ funkcjonowania jednostek $\mathrm{w}$ modelu biernego realizatora podstawowych

${ }^{1}$ Wcześniej dominowała motywacja negatywna, czyli kobiety zmuszone były do podejmowania pracy ze względów ekonomicznych, w celu utrzymania siebie i swojej rodziny. M. Sikorska, Nowa matka, nowy ojciec, nowe dziecko. O nowym układzie sit w polskich rodzinach, Warszawa 2009, s. 84.

${ }^{2}$ Za: E. Krause, O dojrzałości w wyborze pomiędzy kariera zawodowa a macierzyństwem, [w:] Dojrzałość i dojrzewanie. Kategorie - atrybuty - konteksty, red. E. Kubiak-Szymborska, D. Zając, E. Krause, M. Nawrot-Borowska, Bydgoszcz 2018, s. 80-81.

${ }^{3}$ M. Rutkowska, "Nowa kariera" i jej egzemplifikacje w postaci kariery proteuszowej i kariery bez granic, https://www.ipiss.com.pl/wp-content/uploads/downloads/2013/02/m_rutkowska_ zzl_1_2010.pdf, [dostęp: 15.04.2019].

${ }^{4}$ D. Finn, From full employment to employability: a new deal for Britain's unemployed? International Journal of Manpower, 2000, 21(5).

${ }^{5}$ P. Heriot, C. Pemberton, Contracting careers, Human Relations, 1996, 49(6).

${ }^{6}$ Ch. Handy, Wiek przezwyciężonego rozumu, Warszawa 1998, s. 105. 
obowiązków wymaganych przez pracodawcę, z umową o pracę, w kierunku aktywnego, samodzielnego i kreatywnego kreatora ścieżki zawodowej, z silnym naciskiem na aktywność w obszarze całożyciowego uczenia się. Odnosi się to zarówno do edukacji formalnej, pozaformalnej, jak i nieformalnej. Umiejętność czerpania wiedzy w każdym codziennym doświadczeniu edukacyjnym, społecznym i zawodowym, a także sprawne przekładanie jej na umiejętności praktyczne stanowi kluczową współcześnie kompetencję życiową. Warto podkreślić, że w wymiarze badań ilościowych, to właśnie kobiety wykazują wyższy poziom tej umiejętności, niż mężczyźni.

Statystyki wskazują, że wykształcenie wyższe ma więcej Polek niż Polaków ${ }^{7}$. Kobiety są zatem lepiej wyedukowane. Posiadają również wysokie kwalifikacje i kompetencje. Tymczasem najwyższe stanowiska w organizacjach zajmują w zdecydowanej większości mężczyźni. Otoczenie zawodowe nie ułatwia bowiem kobietom awansu i rozwoju zawodowego. Odczuwają one również brak wsparcia ze strony organizacji ${ }^{8}$. Dlatego, ciągle aktualne jest poszukiwanie odpowiedzi na pytania: jakie jest postrzeganie kobiet $\mathrm{w}$ organizacji, w tym jakie zjawiska utrudniają ich rozwój kariery zawodowej oraz rozwiązań wspierających ich sytuację. Rozwój własnej kariery zawodowej szczególnie ważny jest

dla tych kobiet, które pracę zawodową nie traktują tylko instrumentalnie (stanowi ona wówczas głównie źródło dochodów i środek do zaspokojenia podstawowych potrzeb), ale przede wszystkim jako formę samorealizacji życiowej (praca stanowi cel sam w sobie). Jest to podejście autoteliczne, w którym praca jest źródłem radości, satysfakcji, drogą do samorealizacji i aktywnością, z którą można się osobiście identyfikować9.

Artykuł ma na celu zaprezentowanie specyfiki karier zawodowych kobiet we współczesnych organizacjach. Charakterystyka współczesnych organizacji stanowi punkt wyjścia do analizy ścieżek oraz uwarunkowań karier pracowniczych. Zaprezentowano również role społeczne kobiet oraz ich pozycję i znaczenie $\mathrm{w}$ organizacjach. Ponadto, celem autorek jest dostarczenie przesłanek organizacjom do podejmowania dyskursu na temat zjawisk utrudniających rozwój kariery zawodowej kobiet oraz podkreślenie możliwych rozwiązań je wspierających, w tym pozwalających bezkolizyjnie łączyć rozwój kariery zawodowej z wypełnianiem ról rodzinnych.

${ }^{7}$ Zob. dane Głównego Urzędu Statystycznego, np. Szkolnictwo wyższe w roku akademickim 2017/2018 (dane wstępne), 15.06.2018, https://stat.gov.pl/obszary-tematyczne/edukacja/ edukacja/szkolnictwo-wyzsze-w-roku-akademickim-20172018-dane-wstepne,8,5.html?pdf=1, [dostęp: 11.04.2019]; Szkoty wyższe i ich finanse w 2017 r., Warszawa - Gdańsk 2018.

8 Zob. Hays Poland, Kobiety na rynku pracy. Ambicje i wyzwania, Raport 2017; Kobiety na rynku pracy. Równe szanse i elastyczność, Raport 2018.

${ }^{9}$ E. Krause, O dojrzałości w wyborze, s. 80-81. 


\section{Atrybuty organizacji współczesnej}

Funkcjonowanie współczesnych organizacji ${ }^{10} \mathrm{~W}$ ramach gospodarki opartej na wiedzy oraz globalizującego się świata, w kontekście społecznym i ekonomicznym jest związane z koniecznością kształtowania wysokich umiejętności adaptacyjnych i gotowości do uczenia się. Odnosić to można zarówno do kompetencji członków organizacji, czyli jej pracowników, jak i samej organizacji pod kątem jej struktur, strategii, założeń, filozofii działania, a także systemów komunikacyjnych. Adaptacyjność organizacji będzie się objawiała zdolnością do szybkiego reagowania na zmiany w otoczeniu, dostosowywaniu rozwiązań i zasad działania do nowych wymagań rynkowych, podążaniu za ideą traktowania ludzi jako zasobów strategicznych oraz wysoką elastycznością w zakresie hierarchii struktur organizacyjnych. Według Rosabeth Moss Kanter współczesne organizacje są kształtowane przez sześć ważnych zmian filozofii działania, z których każda wywiera istotny wpływ na ludzi i zarządzanie $w$ przedsiębiorstwach ${ }^{11}$. Pierwszy obszar zmian odnosi się do nowej reguły zatrudniania, tak zwane odchudzanie organizacji. Odchudzona organizacja ma ściśle ustalone priorytety i kierunki działań, a jej funkcjonowanie opiera się głównie na outsourcingu, to jest zlecaniu wykonywania pewnych usług przez instytucje zewnętrzne. W takiej firmie wymaga się wydajnej pracy w zwiększonym wymiarze godzin oraz obciążanie załogi dodatkowymi obowiązkami, co skutkuje większą elastycznością i ekonomicznością działania organizacji, jednak nie zapewnia pracownikom poczucia bezpieczeństwa, pewności pracy, czy pożądanego rozwoju kariery. Drugi obszar zmian wiąże się z hierarchią struktur organizacyjnych oraz ewolucją budowanych $\mathrm{w}$ nich zależności od pionowej do poziomej. $\mathrm{W}$ tradycyjnym przedsiębiorstwie skupiano się na przywilejach starszeństwa, gdzie polecenia i priorytety wyznaczało ścisłe kierownictwo, szeregując tym samym pracowników według pozycji, władzy, wynagrodzenia i wpływów. Obecnie więcej zadań jest realizowanych w międzywydziałowych zespołach pracujących nad konkretnymi projektami. Pracowników zachęca się do poszukiwania pomocy i współpracy od równych im rangą innych pracowników, a nie jedynie od ich przełożonych. Takie zachowania pracowników wpisują się w ideę wielowymiarowego uczenia się i dzielenia wiedzą oraz doświadczeniami w przedsiębiorstwach, które można nazwać organizacjami uczącymi sięe . Trzecia zmiana

\footnotetext{
${ }_{10}$ Zob. T.J. Watson, Sociology, work and organisation, London - New York 2012, s. 112-150.

${ }_{11}$ R.M. Kanter, Pozyskiwanie ludzi do organizacji przyszłości, [w:] Organizacja przyszłości, red. F. Hesselbein, M. Goldsmith, R. Beckhard, Warszawa 1998, s. 160-162.

${ }_{12}$ M. Bartkowiak, Kompetencje menedżera a relacje międzypracownicze w organizacji uczacej się, Poznań 2011, s. 42; zob. też. A. Sitko-Lutek, E. Skrzypczak, Organizacyjne uczenie się w rozwoju kompetencji przedsiębiorstw, Warszawa 2009, s. 72-82.
} 
w filozofii działania firm przedstawia nowy obraz zatrudnienia, ewoluujący od jednolitości do różnorodności. W związku ze zdobywaniem przez kobiety i przedstawicieli mniejszości narodowych stanowisk w przedsiębiorstwach oraz postępującą globalizacją rynków wysoko kwalifikowanych specjalistów, miejsca pracy w coraz większym stopniu zapełniają się ludźmi z różnych grup społecznych i kulturowych. Okazuje się, iż firmy tworzące wielokulturowe środowiska pracy, pozbawione działań obciążonych dyskryminacją płci, z powodzeniem realizują swoje strategie, gdyż obecna w nich różnorodność sprzyja twórczości, kreatywności, świeżości pomysłów, gotowości na zmiany oraz wprowadzaniu innowacji. Czwarty obszar zmian wiąże się z nowymi źródłami władzy oraz odchodzeniem od przywilejów stanowiskowych i władzy na rzecz fachowości, otwartości i kontaktów. Okazuje się, iż znaczenia nabierają ci pracownicy, których wartość dla firmy wynika nie tylko z ich umiejętności praktycznych i fachowych, ale także z kontaktów i układów, które mogą wykorzystać na rzecz instytucji. Stąd nasuwa się wniosek, iż niezwykle istotnym atutem kandydata do pracy lub już zatrudnionego pracownika są kompetencje społeczne, dzięki którym w środowisku pracy sprawnie tworzone są sieci kontaktów międzyludzkich, wzajemnej pomocy, wymiany informacji i doświadczeń. Piąty obszar zmian odnosi się do ewolucji lojalności pracowników, która $\mathrm{w}$ tradycyjnym przedsiębiorstwie mierzona była stopniem ich oddania dla pracodawcy. Natomiast w nowoczesnych instytucjach zauważyć można zwiększoną identyfikację pracowników ze świadczoną przez nich pracą (w odróżnieniu do kwestii lojalności wobec pracodawcy) oraz zespołami zadaniowymi, w ramach których działają. Pracownicy wykazujący się nowym typem lojalności dbają o wysoką jakość swojej pracy, gdyż to właśnie ona jest źródłem ich samorealizacji i poczucia wartości, a nie zatrudnienie w konkretnej firmie. Ostatnim, szóstym obszarem przemian jest nowe zdefiniowanie wartości zawodowej - zmniejsza się znaczenie kapitału przedsiębiorstwa na rzecz kapitału reputacji. Tradycyjna kariera pracownika związana była ze wspinaniem się po kolejnych szczeblach stanowisk oraz z rozwojem zawodowym, a budowana była w oparciu o „kapitał organizacji", który pozwalał mu na awanse w obrębie firmy. Obecnie kształtowanie kariery zawodowej nosi znamiona silnego indywidualizmu, a pracownicy polegają przede wszystkim na własnym potencjale oraz skupiają się na takich wartościach i umiejętnościach zawodowych, które będą mogli wykorzystać w wielu miejscach pracy, budując wiarygodną reputację. Ewolucja lojalności, przechodząca od uczciwości wobec organizacji, poprzez pracodawcę, branżę i wykształcenia, aż do „lojalności wobec siebie"13, obrazuje głębokie przemiany w dziedzinie funkcjonowania współczesnych organizacji, a także

${ }^{13}$ N. Hatalska, Praca: scenariusze przyszłości, Warszawa 2016, s. 27-28. 
zachowań ludzi w środowisku pracy i ich wydajności. Siła wpływu na potencjał ludzki w firmie chcącej efektywnie działać na rynku musi ewoluować w kierunku partnerstwa, współdziałania i pobudzania kreatywności, gdyż wszystkie inne zasoby są $\mathrm{w}$ takim samym stopniu dostępne każdej $\mathrm{z}$ organizacji. Jednym z czynników stanowiącym źródło przewagi konkurencyjnej przedsiębiorstw jest kapitał ludzki. Pomimo że polskie organizacje nadal $\mathrm{w}$ niewielkim stopniu adaptują się do zmian w filozofii myślenia i nowych rozwiązań organizacyjnych, można stwierdzić, iż przedsiębiorstwa czy instytucje, które nie zastosują nowoczesnych zasad zarządzania zasobami ludzkimi, nie będą postrzegane jako atrakcyjni pracodawcy, a tym samym nie przyciągną wartościowych i pożądanych obecnie kandydatów do pracy. Co więcej, współcześni pracownicy, zarówno kobiety jak i mężczyźni, oczekują od swoich pracodawców dużo szerszych perspektyw rozwoju, dostosowanych do potrzeb organizacji, ale także osobistych aspiracji jednostek, co znajduje swoje odzwierciedlenie w nowych formach i sposobach realizacji kariery zawodowej.

\section{Kariera zawodowa $w$ organizacji}

Obecna sytuacja na rynku pracy i specyfika karier zawodowych wymaga od jednostki wyjątkowej elastyczności i adaptacyjności. Nie chodzi tylko o zmianę, która w gruncie rzeczy występuje niezależnie od jej woli i trwa bezustannie, lecz przede wszystkim o rozwój, który dokonuje się już przy wysiłku i inicjatywie. Rozwój zawodowy możemy definiować jako „związany z pracą proces indywidualnego wzrostu, zdobywania umiejętności i samorealizowania się"14. Dzięki rozwijaniu i posiadaniu szerokich oraz wszechstronnych umiejętności możemy kształtować świadomie swoją karierę zawodową. Co jednak możemy rozumieć pod pojęciem kariery zawodowej?

Marek Adamiec i Barbara Kożusznik stwierdzają, że tradycyjne pojęcie kariera ma dwa znaczenia: po pierwsze - jest to "droga”, ,trasa”, przebieg życia z pewnego punktu widzenia, po drugie - „kariera” ma charakter wartościujący, określa zmiany życiowe, ale w wyznaczonym, pozytywnym kierunku. Wobec tego ujmują karierę jako „optymalne wykorzystanie własnych zasobów w trakcie pracy i życia osobistego"15. Do rozwoju tak rozumianej kariery potrzebne są co najmniej dwa fundamentalne czynniki. Po pierwsze, analizie poddane powinny być określone warunki wyjściowe kariery, głównie o charakterze psychospołecznym. Takie warunki wyjściowe sprzyjające współcze-

${ }^{14}$ M. Adamiec, B. Kożusznik, Zarządzanie zasobami ludzkimi. Aktor-Kreator-Inspirator, Kraków 2000, s. 262.

${ }_{15}$ Tamże, s. 262-263. 
śnie karierom zawodowym można ująć w następujących grupach: społeczno-ekonomiczne pochodzenie rodziców - ciągle ważny czynnik socjologiczny, który determinuje wybór wykształcenia, zawodu, stylu i poziomu życia; płeć - nadal wyznacza drogę kariery zawodowej, wybór zawodu; zadania emocjonalne okresu dorastania - są to ważne doświadczenia życiowe, które wprowadzają nas w dorosłość i determinują nasze przyszłe możliwości, są to między innymi znalezienie właściwych relacji z rodzicami, pozytywne relacje z rówieśnikami, uniknięcie uzależnień i nałogów, rozwiązanie problemu seksu, skrystalizowanie motywacji do kształcenia się, odnalezienie kierunku własnej edukacji, nabycie samodzielności intelektualnej; zewnętrzne okazje do realizowania własnych predyspozycji i możliwości (potencjału) - są to wszelkie warunki środowiska i sytuacji zewnętrznej sprzyjające wykorzystaniu różnorodnych możliwości ludzkich w trakcie kariery zawodowej, na przykład bogactwo i różnorodność ofert zawodowych. Po drugie, z punktu widzenia rozwoju kariery istotne są optymalne decyzje życiowe i zawodowe, oparte na właściwych kryteriach, to znaczy z jednej strony na gruntownej wiedzy o samym sobie, a z drugiej strony - wiedzy o otoczeniu społecznogospodarczym, jego specyfice, możliwościach i barierach. Decyzje te wiążą się $\mathrm{w}$ zasadzie $\mathrm{z}$ nieustannym podejmowaniem ryzyka, gdyż $\mathrm{w}$ przypadku braku monitorowania bieżących postępów i efektów w rozwoju zawodowym jednostka łatwo powiela znane wzory, schematy i nie potrafi ich przełamać. Dlatego, można jedynie starać się o jak największą optymalizację tych decyzji i podejmować rozsądne ryzyko.

Karierę można również rozumieć inaczej. Analizując literaturę przedmiotu, warto także wskazać na klasyfikację zaproponowaną przez Douglasa Tim Halla ${ }^{16}$, który kategoryzuje liczbę znaczeń tego pojęcia następująco. Kariera jako posuwanie się na przód rozumiana jest jako sekwencja etapów czy awansów, przy czym każde kolejne stanowisko jest, w pewnej globalnej ocenie, "lepsze" niż poprzednie. Stąd, jednostka w celu poprawy swoich przyszłych perspektyw musi wykonywać posunięcia ulepszające, udoskonalające. W przypadku kariery rozumianej jako zawód, nacisk zostaje położony na względnie długi okres wykonywania zawodu i zdobywanie $\mathrm{w}$ nim niezbędnego doświadczenia. Można rozumieć tu karierę jako „uregulowaną przepisami ścieżkę zawodową", którą pracownik pokonuje zdobywając coraz to nowsze i różnorodne kompetencje. Z kolei, określenie kariery jako sekwencję prac na przestrzeni życia, usuwa wartościujący akcent dwu poprzednich definicji i koncentruje się na serii wykonywanych prac i na organizacjach, w których były one wykonywane, abstrahując od konkretnych zawodów czy hierarchii organizacyjnej. Ostatnią kategorią kariery wymienioną w klasyfi-

${ }^{16}$ D.T. Hall, Career is dead, long live the career, San Francisco 1996. 
kacji Halla jest kariera określana jako sekwencja doświadczeń związanych $\mathrm{z}$ rolą życiową człowieka. Jest to najszersza z omawianych definicji i najdalsza od związków z pracą oraz orientacji na posuwanie się do przodu, gdyż położony jest tu nacisk na doświadczenia człowieka związane z jego indywidualnymi rolami. Prawdziwe wydaje się stwierdzenie, że dwa ostatnie typy kariery stanowią najbliższe odzwierciedlenie uwarunkowań współczesnych ścieżek edukacyjno-zawodowych. Podkreślić należy, że obecnie odchodzi się od liniowej, jednowymiarowej kariery w jednej lub maksymalnie dwóch organizacjach, $\mathrm{z}$ naciskiem na realizację siebie w kolejno postępujących etapach kariery, zwieńczonych przygotowaniem się do przejścia na emeryturę i jej urzeczywistnieniem. W wymiarze realizacji kariery zawodowej mamy do czynienia z przejściem od tradycyjnych form działań do tych przedsiębiorczych, innowacyjnych. Dokonując analizy raportów Natalii Hatalskiej ${ }^{17}$, która formułuje pięć kluczowych scenariuszy przyszłości pracy, jasno wyodrębniają się poszczególne czynniki kształtujące wymiary współczesnych karier zawodowych. Autorka ma tu na myśli: wydłużający się czas życia człowieka, tworzenie społeczeństwa wysokich technologii i ich znacząca rola w środowiskach pracy, indywidualizowanie się karier zawodowych, zwiększające się zapotrzebowanie na samodzielnych specjalistów - freelancerów, podkreślanie roli transparentności w budowaniu wizerunku jednostkowego i organizacyjnego oraz zmiany klimatyczne w środowisku. Wyraźnie obserwuje się nacisk na poszerzanie możliwości i perspektyw rozwoju, budowanie wartości dodanej do tradycyjnej ścieżki kariery, większej samodzielności i decyzyjności jednostek oraz wyższe poczucie sprawstwa i potencjału. Grupy pracowników nie podążające za wymogami społeczeństwa technologicznego, wykazujące brak gotowości do całożyciowego uczenia się oraz niechęć do zmiany modelu myślenia, od tradycyjnego do innowacyjnego, znajdą się $\mathrm{w}$ grupie tak zwanych the usless class $^{18}$. Grupa ta to osoby o przeciętnych, średnich kwalifikacjach nie stanowiące w kategorii strategicznego działania organizacji wartości kluczowej w realizowaniu koncepcji społeczno-biznesowej. Dodatkowo, mogą doświadczać wykluczenia społecznego, co z kolei buduje i utrwala poczucie bezradności społecznej. Niezwykle ważnym aspektem jest więc budowanie kompetencji projektowania i realizowania tak zwanej kariery przedsiębiorczej ${ }^{19}$. Opiera się ona na zasadzie działania na rynkach zewnętrznych, a nie środowisk wewnętrznych organizacji. Jest podmiotowo

175 scenariuszy przyszłości pracy: 1 . Working forever; 2 . The useless class; 3 . People per hour; 4 . There are no jobs on the dead planet; 5 . Through the glass door: zob. N. Hatalska, Praca: scenariusze przyszłości; zob. też taże, Raport o wspótczesnych nomadach, Warszawa 2017.

${ }^{18}$ N. Hatalska, Praca, Warszawa 2016.

19 P. Bohdziewicz,Wspótczesnekarieryzawodowe:odmodelubiurokratycznegodoprzedsiębiorczego, https://www.ipiss.com.pl/wp-content/uploads/downloads/2013/02/p_bohdziewicz_zzl_ 3-4_2010.pdf, [dostęp: 23.04.2019]. 
zarządzana przez jednostkę, z respektowaniem zasad dyktowanych przez rynek pracy. Ponadto, jednostka autonomicznie buduje własną zdatność do zatrudniania i atrakcyjność rynkową, które to elementy stanowią kluczową wartość rynkową. Tworzy się profesjonalna tożsamość zawodowa, w ramach której jednostka indywidualnie staje się odpowiedzialna za efekty pracy, co z czasem przedstawia jako swój wyróżniający dorobek edukacyjno-zawodowy. Zadanie realizowania kariery przedsiębiorczej może być różnie odbierane, zarówno przez mężczyzn, jak i kobiety. Mężczyźni z racji większego skupienia na rozwoju zawodowym, rywalizacji oraz mniejszego obciążenia obowiązkami rodzinnymi, łatwiej wchodzą w role aktywnego gracza rynkowego i potrafią szybciej tworzyć unikatową tożsamość zawodową. Kobiety z kolei z jednej strony jako grupa społeczna znacznie bardziej obciążona obowiązkami rodzinnymi mogą postrzegać typ kariery przedsiębiorczej jako zagrożenie ich poczucia stabilizacji i bezpieczeństwa. Z drugiej jednak strony, może dla nich stanowić to szansę na elastyczne łączenie ról życiowych, edukacyjnych i zawodowych oraz większą decyzyjność i autonomię. Współcześnie obserwuje się zwiększającą się liczbę kobiet uprawiających karierę freelancera, w różnych branżach i obszarach ${ }^{20}$.

Anneleen Fourier, Luc Sels, Marijke Verbruggen ${ }^{21}$ wskazują, że dychotomiczny podział na kariery tradycyjne i różne formy tak zwanych nowych karier jest jednak uproszczeniem rzeczywistej sytuacji w tym obszarze. Wymieniają więc oni cztery wzory karier, które w ich opinii wysycają możliwe kategorie realizacji ścieżek zawodowych. Pierwszy wzór to tradycyjna kariera ograniczona, przebiegająca zazwyczaj $\mathrm{w}$ jednej organizacji, z wysoką lojalnością wobec pracodawcy oraz orientacją na stabilizację i bezpieczeństwo zatrudnienia. Drugi wzór to kariera bez granic, realizowana w wielu organizacjach, oparta na różnorodnych zasadach i formach zatrudnienia, z wysoką zmiennością i dynamiką działań, co znajduje swoje odzwierciedlenie nie tylko z wymaganiami organizacji, ale także z wysokim poziomem akceptacji jednostki takiego wzoru niestabilności. Kolejny wzór kariery wiąże się z kształtowaniem monoorganizacyjnej ścieżki przy wewnętrznej orientacji realizatora na zmianę i elastyczność. W ramach tego wzoru kariery można zaobserwować dwa odrębne wymiary działań i nastawienia do pracy jednostki. Pierwszy wariant stanowi zamknięcie w pułapce organizacji, który realizuje się pod wpływem różnych czynników i okoliczności życiowych, zamykających pracownikowi możliwość swobodnego kształtowania ścieżki zawodowej. Drugi wariant odznacza się gotowością do odejścia pracownika, to znaczy wewnętrznym nastawieniem na ciągłe eksplorowanie środowiska w celu znalezienia nowych opcji, lepszych możliwości i bardziej atrakcyjnych perspektyw realizacji kariery. Pracownik realizujący karierę takiego typu to osoba o wysokiej potrzebie działa-

${ }^{20}$ https://freelancemama.pl/wspolpraca/ [dostęp: 30.04.2019]; https://www.wprost.pl/ gospodarka/10141307/praca-freelancera.html [dostęp: 30.04.2019].

${ }^{21}$ A. Fourier, L. Sels, M. Verbruggen, Career counseling in the new era: a study about the influence of career types, career satisfaction and career management on the need for career counseling, Social Science Research Network, Working Paper Series 2005, https://papers.ssrn.com/sol3/papers. cfm?abstract_id=878279 [dostęp: 29.04.2019]. 
nia, dynamiczna, potrzebująca bodźców i dużej różnorodności zadaniowej. Czwarty wzór kariery wskazuje na realizację ścieżki wieloorganizacyjnej przy wewnętrznej orientacji realizatora na stabilność i bezpieczeństwo zatrudnienia. Autorzy wyodrębniają tu także dwie możliwe postawy wobec pracy. Pierwszą kategorię pracowników stanowią osoby nastawiające się na pozostanie $\mathrm{w}$ stanie zatrudnienia u jednego konkretnego pracodawcy, mimo że organizacja nie daje im już takich możliwości. W sytuacji tej to czynniki zewnętrzne wypychają ich z powrotem na rynek, zmuszając do wykazania aktywności w zakresie poszukiwania pracy. Drugą grupę pracowników charakteryzuje tak zwana bezdomność, przejawiająca się w ciągłym poszukiwaniu pracodawcy, u którego mamy nadzieję na stabilność i bezpieczeństwo. W tym wariancie, realizator kariery jest skłaniany do wielokrotnych zmian organizacji.

Dokonując analizy powyższych wzorów kariery, najbardziej adekwatny do wymagań dynamicznego rynku pracy jest wzór drugi i trzeci, gdyż charakteryzuje się wysoką zmiennością, dynamiką, otwartością na różnorodność zadań oraz akceptacją mentalną samych realizatorów takiej postawy pracowniczej. Odnosząc się z kolei do wyborów i ścieżek zawodowych kobiet, można stwierdzić, iż główną tendencją w zakresie ich oczekiwań są nadal tradycyjne wzory karier, opierające się na stabilności, stałości godzin pracy oraz i przede wszystkim możliwości łączenia, godzenia ról społecznych i zawodowych. W związku jednak z silnie zmieniającymi się obecnie trendami karierowymi na rynku, zakładającymi dużą dowolność, elastyczność pracy, dyspozycyjność i nieusystematyzowane godziny pracy, kobiety jako przedstawicielki coraz liczniejszej grupy kluczowych pracowników firmy, zaczynają orientować się na realizację kariery w przestrzeniach niezależnych, samodzielnych profesjonalistów, samozatrudniania i/lub w przestrzeniach chronicznej elastyczności ${ }^{22}$. Kariera typu niezależny mobilny profesjonalizm to kariera specjalistów o wysokiej mobilności i elastyczności zawodowej. Osoby takie zmieniają często organizacje, są otarte na nowe wyzwania, ale w ramach obranej wcześniej specjalizacji zawodowej. Ważnym aspektem jest tutaj budowanie wysokiego poziomu profesjonalizmu, polegającego na gromadzeniu różnorodnych doświadczeń, kumulowaniu wiedzy i dochodzeniu do mistrzostwa osobistego oraz uzyskanie dobrych opinii zleceniodawców i atrakcyjnej reputacji rynkowej. Typ samozatrudnienia charakteryzuje z kolei jednostki funkcjonujące niezależnie w przestrzeni pozaorganizacyjnej. Świadczą one swoje usługi w oparciu o kontrakty z innymi podmiotami gospodarczymi i znajdują satysfakcję z pracy $\mathrm{w}$ wymiarze wolności, swobody i autonomii pra-

${ }^{22}$ W. Mayrhofer, M. Meyer, A. Iellatcitch wyodrębnili 4 typy karier związanych z rodzajem przestrzeni, w jakich są one realizowane: 1 . Kariera w świecie organizacji; 2 . Kariera typu niezależny, mobilny profesjonalizm; 3. Samozatrudnienia; 4. Kariera typu chroniczna elastyczność; patrz: W. Mayrhofer, M. Meyer, A. Iellatcitch, The field od carrer. Towards a new theoretical perspective, Vienna 2001, https://scholar.google.pl/scholar?q=W.+Mayrhofer,+M.+Meyer+2001+carrer\&hl=pl\&as_sdt=0\&as_vis=1\&oi=scholart [dostęp: 28.04 .2019$]$. 
cowniczej. Odnosząc się do typu chronicznej elastyczności, wskazuje się na kluczowy nurt karierowy związany z przekraczaniem różnorodnych granic, na przykład branżowych, organizacyjnych, form zatrudnienia, specjalizacji w zakresie własnej profesji. Zmiany i przejścia często mają wymiar radykalny, fundamentalny. Realizatorzy takiej kariery często działają w oparciu o projekty (just in time), szyte na miarę potrzeb organizacji, dla różnych klientów, wykazując różnorodne aktywności i korzystając z interdyscyplinarnej wiedzy. Okazuje się więc, że w odróżnieniu od stereotypowego założenia, iż to właśnie jeden stabilny pracodawca daje najlepsze możliwości realizacji kariery zawodowej kobiecie, to właśnie formy pracy związane z elastycznością i niezależnością rynkową dają możliwość spełniania ról społecznych i jednoczesnego indywidualnego kreowania przestrzeni zawodowej. Dla kobiet-pracowników możliwość zrównoważonego spełniania licznych oczekiwań społecznych, przy jednoczesnych perspektywach i szansach na rozwój potencjału karierowego, stanowi kluczowe aspekty współczesnego wymiaru pracy. W kolejnych częściach artykułu dokonano prezentacji oraz analizy właśnie tych dwóch obszarów aktywności kobiet, a mianowicie społecznego i zawodowego. Został nakreślony wizerunek współczesnej kobiety, na który składa się wiele różnorodnych ról społecznych oraz konfliktów związanych $\mathrm{z}$ ich pełnieniem. Dokonano również przeglądu zawodowych ról kobiet oraz zjawisk hamujących lub wspierających realizację ich karier w organizacjach.

\section{Kobieta w społeczeństwie}

Współcześnie kobieta może pełnić i pełni w społeczeństwie różnorodne role. Wśród jej ról społecznych ${ }^{23}$ wyróżnia się między innymi następujące:

1) kobieta matka (to najbardziej powszechna rola kobiety, której towarzyszą przekonania, że: „macierzyństwo jest powołaniem każdej kobiety - jest jej podstawową rolą biologiczną i społeczną" ${ }^{24}$, „wszystkie kobiety są stworzone do tego, by być matkami" ${ }^{25}$. Nie wszystkie jednak chcą, szczególnie te mniej konserwatywne i tradycyjne, nimi zostać. Często też odraczają decyzje prokreacyjne, skupiając się na karierze zawodowej. Mimo to rola matki jest

${ }^{23}$ Role społeczne wyróżniono za: P. Olko, G. Filip, Role społeczne odgrywane przez kobietę na przykładzie wybranych czasopism kobiecych, Studia Językoznawcze, 2016, 7, s. 8-22. Celem przywołanych autorek była analiza kobiecych ról społecznych lansowanych w wybranych periodykach skierowanych do kobiet (37 numerów czasopism: „Świat Kobiet”, „Nowy Poradnik Domowy” i „Przyjaciółka” wydanych w latach 2013-2014).

${ }^{24}$ Z. Gawlina, Macierzyństwo jako wartość w kontekście przemian społecznych, [w:] Blaski i cienie życia rodzinnego, red. Z. Tyszka, Poznań 2003, s. 34.

${ }^{25}$ Za: Z. Wojciechowska, Macierzyństwo - czynnik wykluczenia na wspótczesnym rynku pracy czy szansa dla nowych rozwiązań w kobiecej karierze? Edukacja Dorosłych, 2012, 1, s. 79. 
nadal bardzo istotna. Istnieją dwa konkurencyjne i wzajemnie zwalczające się modele macierzyństwa. Jeden bliski tradycji, model „Matki Polki udomowionej” i drugi - nowoczesny model „Matki Polki pracującej”. Odbiór społeczny obu bywa negatywny. Matka Polka poświęcająca swoją karierę wychowaniu dzieci traktowana jest bowiem jako mało ambitna, mająca zawężone horyzonty intelektualne kobieta. Pracującym Matkom Polkom natomiast zarzuca się brak czasu i zaniedbywanie dzieci. Społeczeństwo wymaga jednak od kobiet, aby były dobrą matką i żoną $\left.{ }^{26}\right)$;

2) kobieta żona $i$ kochanka (to zarówno dobra żona, jak i zmysłowa kochanka. Te dwie role musi umiejętnie łączyć. Do jej obowiązków należy opiekowanie się mężczyzną i dbanie o niego);

3) kobieta perfekcyjna pani domu (najbardziej powszechna rola kobiety matki ściśle związana jest z zajmowaniem się domem. Dbanie o porządek sprzątanie, pranie to zajęcia, które przypisywane są kobietom. Czynności te nie należą do wzorca prawdziwego mężczyzny. Stąd najlepiej, jeżeli kobieta zostaje w domu);

4) kobieta kucharka (kuchnia traktowana jest jak jej królestwo. Ma być w tej kwestii zarówno nowoczesna, jak i tradycyjna. Takie stanowisko konsekwentnie i stale przekazywane jest $\mathrm{z}$ pokolenia na pokolenie. Praca zawodowa nie zwalnia z obowiązku zajmowania się kuchnią);

5) kobieta kreatorka wnętrz (może spełniać się w niej zawodowo. Każda jednak może amatorsko urządzać wnętrza, kreować wygląd własnego mieszkania czy domu);

6) kobieta prawniczka (związana jest z dbaniem o bezpieczeństwo rodziny. Kobieta bowiem powinna strzec interesów własnych i swojej rodziny. Obecnie może być dobrą prawniczką w sensie zawodowym i amatorsko. Wskazuje się, że jej obowiązkiem jest wiedzieć, jakie prawa przysługują jej i rodzinie oraz co może zrobić, żeby nie dać się oszukać. Dzięki temu chroni siebie i swoją rodzinę);

7) kobieta robotnik remontowo-budowlany (coraz częściej kobieta spełnia się $\mathrm{w}$ zadaniach przewidzianych dla mężczyzn, np. w pracach remontowo-budowlanych we własnych domach, pokonując w tej kwestii różnorakie przeszkody i łamiąc utrwalone stereotypy);

8) kobieta przedsiębiorcza ekonomistka (współcześnie kobieta coraz częściej decyduje o domowym budżecie. Jako gospodyni i perfekcyjna pani domu może i powinna zadbać także o finanse swojej rodziny, kontrolować wydawane pieniądze i szukać oszczędności. Dzięki temu może wiele zyskać dla swojej rodziny).

${ }^{26}$ Za: I. Pufal-Struzik, Aktywność zawodowa wspótczesnych kobiet - trudności w realizacji nowych ról i tradycyjnych obowiązków, Polskie Forum Psychologiczne, 2017, 22, 2 s. 244. 
Powyższa klasyfikacja wskazuje, że na wizerunek współczesnej kobiety kreowany przez społeczeństwo składa się wiele ról społecznych. Są to role tradycyjne (wychowywanie dzieci, zajmowanie się domem) i nowocześniejsze (kreatorki wnętrz, prawniczki, specjalistki od prac remontowo-budowlanych). Wymienione role $\mathrm{z}$ jednej strony wzmacniają stereotypowe postrzeganie kobiety (utwierdzają ją $w$ tym, że powinna być dobrą matką i perfekcyjną panią domu), a z drugiej daje się zauważyć przełamywanie tego tradycyjnego myślenia. Niewątpliwie, współczesnej kobiecie poszerza się repertuar obowiązków. Nie zawsze także potrafi się odnaleźć w pełnieniu zadań, które narzuca jej społeczeństwo ${ }^{27}$. Podjęcie pracy zawodowej przez kobietę i efektywna realizacja roli zawodowej wymaga również zaangażowania się we własną karierę zawodową. Wiele jednak nie potrafi, bez odczuwania trudności czy stresu, efektywnie łączyć różnych ról z dążeniem do samorealizacji w pracy zawodowej.

W realiach współczesnego społeczeństwa kobieta przeważnie więc funkcjonuje w ramach dwóch ról - rodzinnej i zawodowej. Pełniąc te role, mierzy się z takimi problemami, jak:

- tradycyjne postrzeganie ról kobiet i mężczyzn (tradycyjny model rodziny), stereotypowe postrzeganie kobiety i nierówny podział obowiązków domowych (ciężar takich obowiązków spoczywa przede wszystkim na kobietach, kształtując tym samym ich niekorzystną pozycję na rynku pracy);

- wybór: praca zawodowa/kariera czy rodzina? (chęć samorealizacji w sferze zawodowej często kłóci się z potrzebą, a nawet „obowiązkiem” macierzyństwa);

- niechęć pracodawców do zatrudniania kobiet - bariery w podejmowaniu pracy, osiąganiu awansu i wysokich zarobków (pracodawcy obawiają się, że pracownica-matka będzie częściej korzystała z urlopów i zwolnień lekarskich, przez co będzie mniej dyspozycyjna i efektywna w pracy);

- problemy z powrotem do pracy po przerwie spowodowanej macierzyństwem (często brak alternatywy wobec pracy w pełnym wymiarze godzin, sztywny czas i wymiar pracy);

- trudności z zapewnieniem opieki nad dzieckiem w czasie pracy (niewystarczający dostęp do instytucji opiekuńczych) ${ }^{28}$.

Kobiety stają więc przed problemem dotyczącym zachowania równowagi pomiędzy rolami - rodzinną i zawodową. W analizach dotyczących ich ról punkt ciężkości położony jest na nierówność płci i gorszą pozycję kobiet w większości obszarów aktywności społecznej. Takim obszarem jest zdecydowanie sfera zawodowa. Stąd, warto bliżej przyjrzeć się kobietom w organizacjach, w tym zjawiskom utrudniającym rozwój ich kariery zawodowej.

${ }^{27}$ P. Olko, G. Filip, Role społeczne, s. 22.

${ }_{28}$ Za: E. Krause, Macierzyństwo kobiet-naukowców - o konflikcie roli rodzicielskiej i zawodowej, Szkoła - Zawód - Praca, 2016, 12, s. 155. 


\section{Kobieta w organizacji}

Mimo że na przestrzeni wielu lat pozycja kobiet na rynku pracy uległa pozytywnej zmianie, to wciąż nie można mówić o równouprawnieniu w tej kwestii. W analizie ról zawodowych wskazuje się na niewidoczne przeszkody utrudniające kobietom rozwój kariery zawodowej w organizacjach. Związane są one między innymi z takimi zjawiskami, jak:

- szklana ściana (dyskryminacja zawodowa horyzontalna/pozioma oznaczająca, że kobiety nie mają dostępu do prestiżowych, dobrze płatnych zawodów, branż czy posad, przez co znajdują zatrudnienie w sektorach pomocniczych ${ }^{29}$ );

- szklany sufit (dyskryminacja zawodowa wertykalna/pionowa wskazująca, że kobiety nie są w stanie piąć się po drabinie zawodowej - awansować i osiągać najwyższych szczebli kierowniczych. Tym zbliżającym się do szczytu hierarchii organizacyjnej także jest coraz trudniej awansować. Najwyższe stanowiska decyzyjne $\mathrm{w}$ firmach są przeważnie poza ich zasięgiem - są powyżej sufitu, choć są przez nie zauważane ${ }^{30}$ );

- szklane ruchome schody (to przeciwieństwo szklanego sufitu. Zjawisko to dotyczy działania niewidzialnej siły wynoszącej mężczyzn na wyższe szczeble kariery zawodowej. Funkcjonuje ono oparte na stereotypowym przekonaniu, że mężczyźni, jako grupa, łatwiej podejmują decyzje i stanowiska, które tego wymagają i są one dla nich bardziej odpowiednie niż dla kobiet. Pojawia się głównie w organizacjach, w których mężczyźni stanowią mniejszość - w tzw. sfeminizowanych zawodach. Mimo że większość zatrudnionych stanowią kobiety, to mężczyźni szybciej w nich awansują. Związane jest to z ich większą dyspozycyjnością i determinacją - niekoniecznie kompetencjami $\left.{ }^{31}\right)$;

- szklany klif (oznacza sytuacje, w której praca kobiety na "męskim” stanowisku jest niestabilna, trudna w utrzymaniu i narażona na ciągłą krytykę. Ten rodzaj ostracyzmu nie występuje jednak w odniesieniu do mężczyzn ${ }^{32}$ );

- lepka podtoga (przedstawia sytuacje, w których kobiety "przylepione” są do swojego zawodu i pozycji - dominują w zawodach o niskim prestiżu i niskim dochodzie, gdzie nie ma możliwości awansu, np. sekretarki, sprzątaczki, pomoc domowa. Zjawisko to zatem polega na przypisaniu kobiet do pewnej grupy zawodów mniej prestiżowych i gorzej płatnych $\left.{ }^{33}\right)$;

${ }_{29}$ Za: K. Blicharska-Czubara, Zawodowa rola kobiet w społeczeństwie obywatelskim. Wielowymiarowy model dyskryminacji kobiet. Raport z badania, Szczecin 2011, s. 10.

${ }_{30}$ Za: tamże; Słownik - Równość w Biznesie, SZKLANE ZJAWISKA, https:/ / rownoscwbiznesie.info/szklane-zjawiska-definicja/, [dostęp: 12.04.2019].

31 Za: M. du Vall, M. Majorek, Naukowczynie w polskim systemie szkolnictwa wyższego - trudności i perspektywy, Aequalitas, 2013, 2, 1 (2), s. 8-9.

32 Słownik - Równość w Biznesie, SZKLANE ZJAWISKA.

${ }_{33}$ Za: K. Blicharska-Czubara, Zawodowa rola kobiet w społeczeństwie obywatelskim, s. 10; Stowniczek, http:/ / www.rownoscwbiznesie.mpips.gov.pl/slowniczek.html, [dostęp 12.04.2019]. 
- uciekająca drabina (zjawisko to wiąże z brakiem solidarności wśród kobiet. Te, które są zdeterminowane i silne, realizują swoje kariery dzięki indywidualnym strategiom. Mężczyźni natomiast wzajemnie sobie pomagają, wspierają się i zatrudniają $\left.{ }^{34}\right)$;

- aksamitne getto (określenie opisujące utrudnianie lub niedopuszczanie kobiet do sprawowania stanowisk kierowniczych i decyzyjnych, w tym stanowisk związanych z naukami technicznymi, produkcyjnymi, czy marketingowymi. Zjawisko to opiera się na podtrzymywaniu stereotypowych wzorców kobiet postrzeganych jako opiekunki, strażniczki domowego ogniska ${ }^{35}$ ).

Wskazane zjawiska to metafory niewidzialnych barier, które nie są uzasadnione żadnymi regulacjami prawnymi czy racjonalnymi argumentami. W organizacjach występuje także autodyskryminacja, która „może być przyczyną tego, że rynek pracy nie zmienia się, mimo trwającej od dawna dyskusji na temat równości" ${ }^{\prime 36}$. Kobiety bowiem nierzadko same ustawiają się na pozycjach niższych niż mężczyźni i umniejszają własne kompetencje. Problem nierównych szans w zakresie rozwoju kariery zawodowej często tkwi zatem w nich samych - w niskiej samoocenie, postawie "nie dam rady", obawie przed podejmowaniem nowych zadań, wyzwań, czy zwiększoną odpowiedzialnością (związaną np. z zajmowaniem wysokiego stanowiska) ${ }^{37}$. Przyczyną takiego podejścia, według Beaty Osieckiej, ,jest sposób wychowania i konieczność mierzenia się ze skutkami stereotypów, dotyczących roli kobiet w społeczeństwie" ${ }^{38}$. Należy zwrócić uwagę więc na problem tkwiący w mentalności samych kobiet, dla których możliwość uwolnienia się od stereotypowego ich postrzegania funkcjonuje nadal bardziej w sferze postulatów niż realizacji. Zauważyć zatem można dwie główne grupy przyczyn nierówności kobiet $\mathrm{w}$ organizacjach - zewnętrzne/przedmiotowe (związane z pracodawcami, otoczeniem zawodowym) i wewnętrzne/podmiotowe (tkwiące w samych kobietach).

Współczesne kobiety, szczególnie o aspiracjach do zajmowania stanowisk kierowniczych, zdają sobie sprawę, w jak dużym stopniu na ich sytuację w organizacjach oddziałują stereotypy, uprzedzenia oraz wszystkie czynniki, które ogółem składają się na ich postrzeganie ${ }^{39}$ :

${ }^{34}$ Za: M. du Vall, M. Majorek, Naukowczynie, s. 8.

${ }^{35}$ Stowniczek, http://www.rownoscwbiznesie.mpips.gov.pl/slowniczek.html, [dostęp 12.04.2019].

${ }^{36}$ Hays Poland, Kobiety na rynku pracy. Ambicje i wyzwania, Raport 2017, s. 10.

37 Tamże, s. 17.

38 Tamże.

${ }^{39}$ Czynniki te przedstawiono za Wiolettą Turkowską-Kucharską, która dokonała opisu i próby wyjaśnienia głównych czynników, które wpłynęły na percepcję kobiet w kontekście zajmowania wyższych stanowisk kierowniczych - na tej podstawie przywołana autorka sporządziła wizerunek kobiety menedżera w organizacji: W. Turkowska-Kucharska, Czynniki 
- czynniki merytoryczne/kompetencyjne (są to przede wszystkim posiadane kwalifikacje i kompetencje zawodowe, staż pracy i doświadczenie zawodowe, ale też umiejętności przywódcze oraz gotowość do przekwalifikowania się czy uzupełnienia swoich kwalifikacji. Kobiety mają świadomość dużego znaczenia tych czynników dla pracodawców i starają się sprostać ich oczekiwaniom. Mimo że udział kobiet w zarządzaniu stale wzrasta, to nadal jest on niewspółmierny do wysiłków wkładanych w zdobywanie kwalifikacji i kompetencji. Wciąż także można zaobserwować „presję” w zakresie ich podnoszenia przez kobiety, które w sytuacji zatrudnienia i rywalizacji o objęcie wyższego stanowiska w organizacji muszą „udowodnić”, że są dwa razy lepsze od kandydata mężczyzny. Podejście pań do pracy zawodowej z biegiem czasu jednak zmienia się. Teresa Kupczyk na podstawie własnych badań zauważyła, że: „na początku kariery ambitne kobiety są w stanie dostosowywać się do oczekiwań otoczenia. Z czasem, po zapewnieniu sobie i swojej rodzinie bezpieczeństwa finansowego, nie chcą już płacić tak wysokiej ceny, wolą mniej zarabiać, rezygnują z prestiżu na korzyść równowagi między wszystkimi sferami życia i samorealizacji" $\left.{ }^{40}\right)$;

- czynniki tożsamościowe (często związane z wymiarem emocjonalnym człowieka. Badania Daniela Golemana ${ }^{41}$ wskazują, że kobiety przeważnie cechują się bardziej rozwiniętą inteligencją emocjonalną niż mężczyźni - lepiej rozumieją drugiego człowieka i jego zachowania, łatwiej przychodzi im nawiązanie kontaktów interpersonalnych oraz podtrzymanie tych relacji, są bardziej empatyczne i skłonniejsze do ustępstw. Ponadto cechuje je mniejsza skłonność do rywalizacji - ich styl zarządzania przypomina relacje partnerskie. Przynosi to korzyści organizacji, wpływa pozytywnie na pracę i jej skuteczność. Kompetencje osobowościowe i społeczne są konieczne, aby można było mówić o odniesieniu sukcesu zawodowego. Kobietom jednak niekiedy brakuje pewności siebie, ambicji, motywacji oraz wiary w siebie i swoje możliwości);

- czynniki biologiczne (w kontekście podejmowanej problematyki czynnikiem tym jest płeć. To na jego podstawie organizacja ma możliwość postrzegania kobiety w konkretny sposób - zbieżny bądź sprzeczny z kulturowym postrzeganiem. Styl zarządzania preferowany przez kobiety przeważnie opiera się na partnerstwie, otwartości i zaufaniu. Jak podkreśla Wioleta Turkowska-Kucharska: „często odnosi się wrażenie, że jest on dla nich czymś zupełnie naturalnym. Tak jakby był zapisany w kobiecych genach. Jest to specyficzny sposób kierowania, którego trudno byłoby się wyuczyć. To sprawia,

warunkujące znaczenie kobiet menedżerów w zarządzaniu organizacją, [w:] Zarządzanie wartościami niematerialnymi w erze gospodarki cyfrowej, red. W. Harasim, Warszawa 2015, s. 66-73.

${ }^{40}$ T. Kupczyk, Kobiety w zarzadzaniu i czynniki ich sukcesów, Wrocław 2009, s. 51.

${ }^{41}$ Zob. D. Goleman, Inteligencja emocjonalna w praktyce, Poznań 1999. 
że predyspozycje i naturalny potencjał jaki posiadają kobiety dzięki biologii i kulturze, w pełni może być przez nie wykorzystywany na kierowniczych stanowiskach $w$ pełnieniu roli lidera. Nawet element wrażliwości, który kojarzony jest z kobietami i długo postrzegany był jako wada wśród cech menedżerów, dziś jest dodatkowym atutem" ${ }^{42}$ );

- czynniki ekonomiczne (wiążą się z zajmowaną pozycją i statusem społecznym, ale także $\mathrm{z}$ wyglądem kobiety. Wiele $\mathrm{z}$ nich zdaje sobie sprawę, że połączenie takich czynników, jak kompetencje, cechy osobowości, wraz z odpowiednim wizerunkiem zewnętrznym tworzy całokształt ich postrzegania sprzyjający sprawom zawodowym. Wioleta Turkowska-Kucharska zwraca uwagę, że: „odpowiedni dobór stroju i dodatków, może być czynnikiem, który znacząco wpłynie na percepcję kobiety jako osoby o dobrym guście, wartościowej czy majętnej" ${ }^{\prime 3}$ );

- czynniki rodzinne (dla organizacji życie rodzinne kobiety to sfera będąca istotnym elementem w jej postrzeganiu. Realizacja kariery zawodowej nierzadko staje się powodem, dla którego kobiety na stanowiskach kierowniczych odraczają swoje decyzje prokreacyjne. W sytuacji kobiety ubiegającej się o stanowisko kierownicze i jednocześnie pełniącej rolę rodzica, oczekiwania pracodawców dotyczą jej dyspozycyjności, odpowiedzialności, zaangażowania, samodzielności. Sprawia to, że doświadczają wielu trudności w godzeniu życia zawodowego z życiem rodzinnym - konfliktów ról oraz innych napięć i sprzeczności. Stąd, tak istotne jest znalezienie równowagi pozwalającej na łączenie wszystkich ról społecznych bez wyrzutów sumienia, że któraś jest zaniedbywana);

- czynniki związane ze strukturą, zawodem oraz karierą (związane są one $\mathrm{z}$ zaspokojeniem potrzeby rozwoju, spełnienia, czy samorealizacji. W wyniku tego, że coraz częściej można zauważyć istnienie warunków, rozwiązań pozwalających na łączenie kariery zawodowej z życiem rodzinnym, w szczególności z rolą rodzicielską, kobiety mogą spełniać się w obu sferach - rodzinnej i zawodowej. To właśnie kwestia samorealizacji staje się obecnie dla kobiet jednym z istotnych aspektów. Sprzyjają temu przemiany społeczno-kulturowe, zmiany na rynku pracy i w świadomości samych kobiet. Powód podejmowania aktywności zawodowej nie jest już jedynie finansowy. Sprawia, że organizacje coraz chętniej zatrudniają kobiety, które chcą rozwijać własną karierę zawodową).

Jak wskazuje powyższa analiza, istnieje wiele czynników decydujących o postrzeganiu kobiet jako wartości niematerialnej w procesie zarządzania organizacjami.

\footnotetext{
${ }^{42}$ W. Turkowska-Kucharska, Czynniki warunkujące znaczenie kobiet menedżerów, s. 70.

${ }^{43}$ Tamże, s. 71.
} 
Według badań POP UP GRUPA, prowadzonych w organizacjach, wyłaniają się trzy typy kobiet $\mathrm{w}$ biznesie:

1) kobieta szef-zarządca (cechuje ją męski styl zarządzania i chęć udowodnienia, że jest lepsza od każdego mężczyzny. Najważniejsze dla niej są skuteczność i efektywność. Stosunek otoczenia do niej można określić jako mieszankę strachu i niechęci);

2) kobieta przyjaciótka/opiekunka (zdecydowanie dominuje u niej kobiecy styl zarządzania i chęć pokazania, że w kobiecych cechach tkwi ogromna moc. Jest ona bardzo empatyczna, wyrozumiała. Swoją pozycję buduje na narracji „siła kobiecości”. Współpracowników traktuje jako rodzinę niemającą zadań do wykonania, tylko wspólne wyzwania. To taka kobieta "matka”, która jest postrzegana bardziej jako miła niż efektywna. Otoczenie lubi z nią pracować);

3) kobieta liderka (charakteryzuje ją ani kobiecy, ani męski styl zarządzania, ponieważ ma ona własny styl. Płeć nie stanowi dla niej tematu do dyskusji w pracy. Posiada ugruntowaną pewność siebie, powodującą, że nikomu niczego nie musi udowadniać. Realizacja celów oznacza dla niej samorealizację na poziomie funkcjonalnym i emocjonalnym) ${ }^{44}$.

Podsumowując kwestie dotyczące ról kobiet w społeczeństwie i organizacji, należy zauważyć, że podejmują one różne role, doświadczając wielu barier czy trudności zarówno o charakterze zewnętrznym (związanymi m.in. ze stereotypami, zjawiskami dyskryminującymi), jak i wewnętrznym (autostereotypy, autodyskryminacja). Kobiety stanowią jednak ponad połowę społeczeństwa, są lepiej wykształcone i we współczesnych organizacjach mogą dysponować dużą częścią strategicznego potencjału rozwojowego. Odpowiednie wykorzystanie kobiecych talentów to inwestycja pozwalająca organizacjom na efektywniejszy jej rozwój.

\section{Podsumowanie}

W literaturze przedmiotu podkreśla się nierówność płci i gorszą pozycję kobiet na rynku pracy. Stąd, ważne jest ciągłe podejmowanie dyskursu na temat zjawisk utrudniających ich rozwój kariery zawodowej oraz określanie rekomendacji dla organizacji - możliwych rozwiązań je wspierających, w tym pozwalających bezkolizyjnie łączyć pracę zawodową z wypełnianiem ról rodzinnych.

Rozwiązania wspierające kobiety zostały zawarte w trzech rekomendacjach dla organizacji, które zostały opracowane przez Hays Poland na podstawie raportu: Kobiety na rynku pracy. Równe szanse i elastyczność. Pierwszą z nich

${ }^{44}$ POP UP GRUPA, Jaki jest wizerunek kobiet w biznesie? [08.03.2018], http:/ / www.proto.pl/ aktualnosci/jaki-jest-wizerunek-kobiet-w-biznesie [dostęp: 12.04.2019]. 
jest wspieranie rozwoju karier kobiet, które nie aspirują do obejmowania stanowisk dyrektorskich i zarządczych tak samo często jak mężczyźni. O awans natomiast ubiegają się równie często. Stąd wniosek, że

kobietom brakuje wsparcia otoczenia zawodowego $\mathrm{w}$ ich dążeniu do objęcia ról wyższego szczebla. Pracodawcy powinni przede wszystkim inwestować w szkolenia i rozwój utalentowanych profesjonalistek, zapewnić im dostęp do programów mentoringowych oraz podejmować decyzje o awansach na podstawie kwalifikacji i doświadczenia kandydatów. Celem powinno być wspieranie pewności siebie oraz wzmacnianie przekonania, że pracę można łączyć ze zobowiązaniami rodzinnymi i osobistymi ${ }^{45}$.

Jedną z największych trudności, z jaką w karierze zawodowej zmagają się kobiety jest powrót do pracy po dłuższej nieobecności (np. urlopie macierzyńskim czy wychowawczym). Według badania Hays Poland

taka sytuacja jest wyjątkowo stresującym okresem dla pracujących matek, w szczególności gdy pracodawca naciska na szybszy powrót do pracy lub gdy niemożliwy jest powrót na uprzednio zajmowane stanowisko. Wdrożenie programu ułatwiającego powrót do pracy po dłuższej nieobecności znalazło się wśród najlepiej ocenianych rozwiązań wspierających realizację ambicji zawodowych kobiet. Firmy powinny ułatwić pracownicom powrót, oferując im czas na ponowne wdrożenie w obowiązki oraz umożliwić pogodzenie pracy zawodowej z opieką nad dzieckiem ${ }^{46}$.

Odnosząc się do drugiego zalecenia, jakim jest praca coraz bardziej elastyczna, należy uznać, że taka możliwość jest dla kobiet niezwykle ważna, bowiem

ułatwia zachowanie równowagi pomiędzy życiem zawodowym a prywatnym, co jest szczególnie istotne dla osób wychowujących dzieci. Kobiety chętniej będą planować swoją zawodową przyszłość, jeśli będą mogły przynajmniej częściowo dopasować godziny i miejsce pracy do zobowiązań rodzinnych ${ }^{47}$.

Organizacje powinny więc dopasować sposób wykonywania pracy do oczekiwań swoich pracowników. Takie rozwiązanie jednocześnie poprawia sytuację kobiet na rynku pracy ${ }^{48}$.

Ostatnie zalecenie zwraca uwagę na konieczność różnorodności płciowej. Organizacje dostrzegają problem jej braku lub nierównych szans kobiet i mężczyzn w dziedzinie rozwoju ich karier zawodowych. Bariery utrudniające awans kobietom to dominujące style zarządzania nieuwzględniające ich sytuacji i doświadczeń. Wymóg pełnej dyspozycyjności też nie pomaga. Ko-

\footnotetext{
${ }^{45}$ Hays Poland, Kobiety na rynku pracy. Równe szanse i elastyczność, Raport 2018, s. 41.

${ }^{46}$ Hays Poland, Kobiety na rynku pracy. Ambicje, s. 33.

${ }^{47}$ Hays Poland, Kobiety na rynku pracy. Równe szanse, s. 41.

48 Tamże.
} 
nieczna jest więc zmiana kultury organizacyjnej na rzecz promowania różnych stylów. Jest to korzystne nie tylko dla samych kobiet, ale także dla efektywności działania organizacji. Promocja i docenianie różnorodności może się odbywać dzięki konkretnie zdefiniowanemu systemowi oceny i awansu pracowników ${ }^{49}$. Przytoczone rekomendacje służą polepszaniu sytuacji zawodowej kobiet w organizacjach, a w szczególności tych łączących role rodzinne i zawodowe.

\section{BIBLIOGRAFIA}

Adamiec M., Kożusznik B., Zarządzanie zasobami ludzkimi. Aktor-Kreator-Inspirator, Wydawnictwo Akade, Kraków 2000.

Bartkowiak M., Kompetencje menedżera a relacje międzypracownicze w organizacji uczacej się, Wydawnictwo Naukowe UAM, Poznań 2011.

Blicharska-Czubara K., Zawodowa rola kobiet w społeczeństwie obywatelskim. Wielowymiarowy model dyskryminacji kobiet. Raport z badania, Wojewódzki Urząd Pracy w Szczecinie, Szczecin 2011.

Du Vall M., Majorek M., Naukowczynie w polskim systemie szkolnictwa wyższego - trudności i perspektywy, Aequalitas, 2013, 2, 1(2).

Gawlina Z., Macierzyństwo jako wartość w kontekście przemian społecznych, [w:] Blaski i cienie życia rodzinnego, red. Z. Tyszka, Roczniki Socjologii Rodziny, tom XV, Poznań 2003.

Główny Urząd Statystyczny, Szkoły wyższe i ich finanse w 2017 r., Warszawa - Gdańsk 2018.

Goleman D., Inteligencja emocjonalna w praktyce, Media Rodzina, Poznań 1999.

Hall D.T., Career is dead, long live the career, Jossey Bass, San Francisco 1996.

Handy Ch., Wiek przezwyciężonego rozumu, Business Press, Warszawa 1998.

Hatalska N., Praca: scenariusze przyszłości, Infuture Hatalska Foresight Institute, Warszawa 2016.

Hatalska N., Raport o wspótczesnych nomadach, Infuture Hatalska Foresight Institute, Warszawa 2017.

Hays Poland, Kobiety na rynku pracy. Ambicje i wyzwania, Raport 2017.

Hays Poland, Kobiety na rynku pracy. Równe szanse i elastyczność, Raport 2018.

Kanter R.M., Pozyskiwanie ludzi do organizacji przyszłości, [w:] Organizacja przyszłości, red. F. Hesselbein, M. Goldsmith, R. Beckhard, Business Press, Warszawa 1998.

Korcz I., Pietrulewicz B., Kariera zawodowa, Instytut Edukacji Techniczno-Informatycznej UZ, Zielona Góra 2003.

Krause E., Macierzyństwo kobiet-naukowców - o konflikcie roli rodzicielskiej i zawodowej, Szkoła - Zawód - Praca, 2016, 12.

Krause E., O dojrzałości w wyborze pomiędzy kariera zawodowa a macierzyństwem, [w:] Dojrzatość i dojrzewanie. Kategorie - atrybuty - konteksty, red. E. Kubiak-Szymborska, D. Zając, E. Krause, M. Nawrot-Borowska, Wydawnictwo Uniwersytetu Kazimierza Wielkiego, Bydgoszcz 2018.

Kupczyk T., Kobiety w zarządzaniu i czynniki ich sukcesów, Wydawnictwo Wyższej Szkoły Handlowej, Wrocław 2009.

49 Tamże. 
Olko P., Filip G., Role społeczne odgrywane przez kobiete na przykładzie wybranych czasopism kobiecych, Studia Językoznawcze, 2016, 7.

Pufal-Struzik I., Aktywność zawodowa wspótczesnych kobiet - trudności w realizacji nowych ról i tradycyjnych obowiązków, Polskie Forum Psychologiczne, 2017, 22, 2.

Sikorska M., Nowa matka, nowy ojciec, nowe dziecko. O nowym układzie sit w polskich rodzinach, Wydawnictwo Akademickie i Profesjonalne, Warszawa 2009.

Sitko-Lutek A., Skrzypczak E., Organizacyjne uczenie się w rozwoju kompetencji przedsiębiorstw, Wydawnictwo Beck, Warszawa 2009.

Turkowska-Kucharska W., Czynniki warunkujące znaczenie kobiet menedżerów w zarządzaniu organizacja, [w:] Zarządzanie wartościami niematerialnymi w erze gospodarki cyfrowej, red. W. Harasim, Wyższa Szkoła Promocji, Mediów i Show Businessu, Warszawa 2015.

Watson T.J., Sociology, work and organisation, Sixth edition, Published by Routledge, London - New York 2012.

Wojciechowska Z., Macierzyństwo - czynnik wykluczenia na wspótczesnym rynku pracy czy szansa dla nowych rozwiazań w kobiecej karierze? Edukacja Dorosłych, 2012, 1.

\section{Netografia}

Bohdziewicz P., Wspótczesne kariery zawodowe: od modelu biurokratycznego do przedsiębiorczego, https://www.ipiss.com.pl/wp-content/uploads/downloads/2013/02/p_bohdziewicz_zzl_3-4_2010.pdf, [dostęp: 23.04.2019].

Fourier A., Sels L., Verbruggen M., Career counseling in the new era: a study about the influence of career types, career satisfaction and career management on the need for career counseling, Social Science Research Network, Working Paper Series 2005.

Główny Urząd Statystyczny, Szkolnictwo wyższe w roku akademickim 2017/2018 (dane wstępne), 15.06.2018, https://stat.gov.pl/obszary-tematyczne/edukacja/edukacja/ szkolnictwo-wyzsze-w-roku-akademickim-20172018-dane wstepne,8,5.html?pdf=1， [dostęp: 11.04.2019].

Mayrhofer W., Meyer M., Iellatcitch A., The field od carrer. Towards a new theoretical perspective, Interdyscyplinary Department of Management and Organisational Behaviour Vienna 2001, https://scholar.google.pl/scholar?q=W.+Mayrhofer,+M.+Meyer+2001+carrer\&hl=pl\&as_sdt=0\&as_vis=1\&oi=scholart [dostęp: 28.04 .2019$]$.

POP UP GRUPA, Jaki jest wizerunek kobiet w biznesie? [08.03.2018], http://www.proto.pl/ aktualnosci/jaki-jest-wizerunek-kobiet-w-biznesie [dostęp: 12.04.2019].

Rutkowska M., "Nowa kariera” i jej egzemplifikacje w postaci kariery proteuszowej i kariery bez granic, https://www.ipiss.com.pl/wpcontent/uploads/downloads/2013/02/m_rutkowska_zzl_1_2010.pdf, [dostęp: 15.04.2019].

Stowniczek, http:/ / www.rownoscwbiznesie.mpips.gov.pl/slowniczek.html, [dostęp:12.04. 2019].

Słownik - Równość w Biznesie, SZKLANE ZJAWISKA, https://rownoscwbiznesie.info/ szklane-zjawiska-definicja/ [dostęp: 12.04.2019].

https:/ / papers.ssrn.com/sol3/papers.cfm?abstract_id=878279 [dostęp: 29.04.2019].

https://freelancemama.pl/wspolpraca/ [dostęp: 30.04.2019].

https://www.wprost.pl/gospodarka/10141307/praca-freelancera.html [dostęp: 30.04 . 2019]. 